\title{
SARS-CoV-2 productively infects human gut enterocytes
}

\author{
Mart M. Lamers ${ }^{1 *}$, Joep Beumer ${ }^{2 *}$, Jelte van der Vaart ${ }^{2 *}$, Kèvin Knoops $^{3}$, Jens Puschhof ${ }^{2}$, Tim I. Breugem, \\ Raimond B. G. Ravellï ${ }^{3}$, J. Paul van Schayck ${ }^{3}$, Anna Z. Mykytyn', Hans Q. Duimel ${ }^{3}$, Elly van Donselaar ${ }^{3}$, Samra \\ Riesebosch', Helma J. H. Kuijpers ${ }^{3}$, Debby Schippers', Willine J. van de Wetering ${ }^{3}$, Miranda de Graaf', Marion \\ Koopmans ${ }^{1}$, Edwin Cuppen ${ }^{4,5}$, Peter J. Peters ${ }^{3}$, Bart L. Haagmans ${ }^{1} \uparrow$, Hans Clevers $^{2}+\ddagger$

\begin{abstract}
${ }^{1}$ Viroscience Department, Erasmus Medical Center, Rotterdam, Netherlands. ${ }^{2}$ Oncode Institute, Hubrecht Institute, Royal Netherlands Academy of Arts and Sciences and University Medical Center, Utrecht, Netherlands. ${ }^{3}$ The Maastricht Multimodal Molecular Imaging Institute, Maastricht University, Maastricht, Netherlands. ${ }^{4} \mathrm{Center}$ for Molecular Medicine and Oncode Institute, University Medical Centre Utrecht, Utrecht, Netherlands. ${ }^{5}$ Hartwig Medical Foundation, Amsterdam, Netherlands.

*These authors contributed equally to this work.
\end{abstract}

†These authors contributed equally to this work.

‡Corresponding author. Email: h.clevers@hubrecht.eu (H.C.); b.haagmans@erasmusmc.nl (B.L.H.)

The virus severe acute respiratory syndrome-coronavirus 2 (SARS-CoV-2) can cause coronavirus disease 2019 (COVID-19), an influenza-like disease that is primarily thought to infect the lungs with transmission via the respiratory route. However, clinical evidence suggests that the intestine may present another viral target organ. Indeed, the SARS-CoV-2 receptor angiotensin converting enzyme 2 (ACE2) is highly expressed on differentiated enterocytes. In human small intestinal organoids (hSIOs), enterocytes were readily infected by SARS-CoV and SARS-CoV-2 as demonstrated by confocal- and electron-microscopy. Consequently, significant titers of infectious viral particles were detected. mRNA expression analysis revealed strong induction of a generic viral response program. Hence, intestinal epithelium supports SARSCoV-2 replication, and hSIOs serve as an experimental model for coronavirus infection and biology.

Severe acute respiratory syndrome (SARS), caused by coronavirus SARS-CoV, emerged in 2003 (1). In late 2019, a novel transmissible coronavirus (SARS-CoV-2) was noted to cause an influenza-like disease ranging from mild respiratory symptoms to severe lung injury, multi-organ failure, and death (2-4). SARS-CoV and SARS-CoV-2 belong to the Sarbecovirus subgenus (genus Betacoronavirus, family Coronaviridae) (5-7). The SARS-CoV receptor is the angiotensinconverting enzyme 2 (ACE2) $(8,9)$. The spike proteins of both viruses bind to ACE2, whereas soluble ACE2 blocks infection by SARS-CoV as well as by SARS-CoV-2 (10-13). Transmission of SARS-CoV-2 is thought to occur through respiratory droplets and fomites. The virus can be detected in upper respiratory tract samples, implicating the nasopharynx as site of replication. In human lung, ACE2 is expressed mainly in alveolar epithelial type II cells and ciliated cells (14-16). However, highest expression of ACE2 in the human body occurs in the brush border of intestinal enterocytes $(14,17)$. Even though respiratory symptoms dominate the clinical presentation of COVID-19, gastrointestinal symptoms are observed in a subset of patients $(18,19)$. Moreover, viral RNA can be found in rectal swabs, even after nasopharyngeal testing has turned negative, implying gastro-intestinal infection and a fecal-oral transmission route $(20-22)$.

SARS-CoV-2 infects airway and gut organoids Organoids are 3D structures, that can be grown from adult stem cells (ASCs) and recapitulate key aspects of the organ from which the ASCs derive. Since SARS-CoV and SARS-CoV2 target the lung, we added virus to organoid-derived human airway epithelium cultured in 2D and observed that SARS$\mathrm{CoV}$ and SARS-CoV2 readily infected differentiated airway cultures. (Fig. 1A). Immunostaining reveal that the viruses targeted ciliated cells, but not goblet cells (Fig. 1, B and C).

Human small intestinal organoids (hSIOs) are established from primary gut epithelial stem cells, can be expanded indefinitely in 3D culture and contain all proliferative and differentiated cell types of the in vivo epithelium (23). Of note, hSIOs have allowed the first in vitro culturing of Norovirus (24). We exposed ileal hSIOs grown under four different culture conditions ('EXP', 'DIF', 'DIF-BMP' and 'EEC') to SARSCoV and SARS-CoV-2 at a multiplicity of infection (MOI) of 1. hSIOs grown in Wnt-high expansion medium (EXP) overwhelmingly consist of stem cells and enterocyte progenitors. Organoids grown in differentiation medium (DIF) contain enterocytes, goblet cells, and low numbers of enteroendocrine cells (EECs). Addition of BMP2/4 to DIF (DIF-BMP) leads to further maturation (25). In the final condition, we induced expression of NeuroG3 from a stably transfected vector with doxycycline to raise EECs numbers (fig. S3D). Samples were harvested at multiple timepoints post infection and processed for the analyses given in Figs. 2 to 5. Both SARS$\mathrm{CoV}$ and SARS-CoV-2 productively infected hSIOs as assessed by qRT-PCR for viral sequences and by live virus titrations on 
VeroE6 cells (see Fig. 2 for lysed organoids and fig. S1 for organoid supernatant). Infectious virus particles and viral RNA increased to significant titers for both viruses in all conditions. Since EXP medium supported virus replication (Fig. 2, $\mathrm{A}$ and $\mathrm{E}$ ), enterocyte progenitors appeared to be a primary viral target. Differentiated organoids (DIF; DIF-BMP) produced slightly (non-statistically significant) lower levels of infectious virus (Fig. 2 and fig. S1). In organoids induced to generate EECs, virus yields were similar to those in EXP medium (Fig. 2, D and H). In differentiated hSIOs, SARS-CoV-2 titers remained stable at 60 hours post infection, whereas SARS-CoV titers dropped 1-2 log (Fig. 2, B, C, F, and G). The latter decline was not observed in infected hSIOs grown in EXP. Culture supernatants across culture conditions contained lower levels of infectious virus compared to lysed hSIOs, implying that virus was primarily secreted apically (fig. S1, A to D). Despite this, viral RNA was detected readily in culture supernatants correlating with the infectious virus levels within hSIOs (Fig. 2, E to H, and fig. S1, E to H).

ACE2 mRNA expression differed greatly between the four conditions. EXP-hSIOs express 300-fold less ACE2 mRNA compared to DIF-hSIOs, when analyzed in bulk (fig. S2). BMP treatment induced 6.5-fold up-regulation of ACE2 mRNA compared to DIF treatment alone. Since this did not yield infection rate differences, the DIF-BMP condition was not analyzed further.

\section{SARS-CoV-2 infects enterocyte lineage cells}

To determine the target cell type, we then performed confocal analysis on hSIOs cultured in EXP, DIF, or EEC conditions. We stained for viral dsRNA, viral nucleocapsid protein, KI67 to visualize proliferative cells, actin (using phalloidin) to visualize enterocyte brush borders, DNA (DAPI) and cleaved caspase 3 to visualize apoptotic cells. Generally, comparable rates of viral infections were observed in the organoids growing in all three conditions. We typically noted staining for viral components (white) in rare, single cells at 24 hours. At 60 hours, the number of infected cells had dramatically increased (Fig. 3A). Infected cells invariably displayed proliferative enterocyte progenitor-phenotypes (EXP; Fig. 3B, top) or ApoA1+ enterocyte-phenotypes (DIF; Fig. 3B, bottom). Of note, SARS-CoV also readily infected enterocyte lineage cells (fig. S3, A and B) as shown previously $(26,27)$. Some infected enterocyte progenitors were in mitosis (fig. S3C). Whereas EEC-organoids produced appreciable titers, we never observed infection of Chromogranin-A ${ }^{+}$EECs (fig. S3, D and E). We also did not notice infection of Goblet cells across culture conditions. At 60 hours, apoptosis became prominent in both SARS-CoV and SARS-CoV-2 infected enterocytes (fig. S5). ACE2 protein was readily revealed as a bright and ubiquitous brush border marker in hSIOs in DIF medium (Fig. 3C). In hSIOs in EXP medium, ACE2 staining was much lower -yet still apical- in occasional cells in a subset of organoids that displayed a more mature morphology (Fig. 3C). In immature (cystic) organoids within the same cultures, the ACE2 signal was below the detection threshold. The percentage of infected organoids under EXP and DIF conditions are given in fig. S4. Figure S5 shows images and quantification of apoptotic cells upon infection.

\section{Ultrastructural analysis of the viral life cycle in entero- cytes}

Unsupervised transmission electron microscopy (TEM) (28) was performed on selected highly infected samples. Figure 4 shows two hSIOs, selected from 42 imaged hSIOs at 60 hours post SARS-CoV-2 infection. These differ in the state of infection: whereas the cellular organization within organoid 1 was still intact (Fig. 4A, entire organoid; B to D, intermediate magnification; $\mathrm{E}$ to $\mathrm{K}$, high magnification), many disintegrated cells can be seen in organoid 2 (Fig. 4, bottom; L, entire organoid; $\mathrm{M}$ to $\mathrm{O}$, intermediate magnification; $\mathrm{P}$ to $\mathrm{R}$, high magnification). Viral particles of $80-120 \mathrm{~nm}$ occurred in the lumen of the organoid (Fig. 4I), at the basolateral (Fig. $4 \mathrm{~J}$ ) and apical side (Fig. 4K) of enterocytes. The double-membrane vesicles which are the subcellular site of viral replication (29) are visualized in Fig. 4, E and P. The nuclei in both organoids differed from nuclei in mock-infected organoids by a slightly rounder shape. The nuclear contour index (30) was $4.0+/-0.5$ vs $4.3+/-0.5$ for control set. There was more heterochromatin $(4 \mathrm{~N})$, and one or two dense nucleoli in the center $(4 \mathrm{O})$.

\section{RNA expression changes in infected enterocytes}

We then performed mRNA sequence analysis to determine gene expression changes induced by SARS-CoV and SARSCoV-2-infection of hSIOs cultured continuously in EXP medium and hSIOs cultured in DIF medium. Infection with SARS-CoV-2 elicited a broad signature of cytokines and interferon stimulated genes (ISGs) attributed to type I and III interferon responses (Fig. 5A and tables $\mathrm{S} 1$ and $\mathrm{S} 2$ ), as confirmed by Gene Ontology analysis (Fig. 5B). An overlapping list of genes appeared in SARS-CoV-2-infected DIF organoids (fig. S6 and table S3). RNA sequencing analysis confirmed differentiation of DIF organoids into multiple intestinal lineages, including ACE2 up-regulation (fig. S7). SARS-CoV also induced ISGs, yet to a much lower level (table S4). Figure $5 \mathrm{C}$ visualizes the regulation of SARS-CoV-2induced genes in SARS-CoV infected organoids. This induction was similar to infections with other viruses like norovirus (31), rotavirus (32) and enteroviruses (33, 34). A recent study (35) describes an antiviral signature induced in human cell lines after SARS-CoV-2 infection. Whereas the ISG response is broader in intestinal organoids, the induced gene sets are in close agreement between the two datasets 
(fig. S8). One striking similarity was the low expression of Type I and III interferons: we only noticed a small induction of the Type III interferon IFNL1 in SARS-CoV-2 infected organoids. In SARS-CoV-infected organoids, we did not observe any type I or type III interferon induction. We confirmed these findings by ELISA on culture supernatant and qRTPCR, which in addition to IFNL1 picked up low levels of type I interferon IFNB1 in SARS-CoV-2 but not in SARS-CoV infected organoids (fig. S9). The specific induction of IP10/CXCL10 and ISG15 by SARS-CoV-2 was also confirmed by ELISA and qRT-PCR, respectively (fig. S10). As in (35), a short list of cytokine genes was induced by both viruses albeit it to modest levels. For a comparison with (35), see fig. S11. Altogether these data indicate that SARS-CoV-2 induces a stronger interferon response than SARS-CoV in HIOs.

Finally, the infection was repeated in a second experiment in the same ileal HIO line and analyzed after 72 hours. Analysis involved viral titration (fig. S12), confocal imaging (fig. S13), and RNA sequencing (fig. S14). This experiment essentially confirmed the observations presented above. A limited, qualitative experiment applying confocal analysis demonstrated infectability of two other lines available in the lab (one ileal, one duodenal) from independent donors (fig. S13). This study shows that SARS-CoV and SARS-CoV-2 infect enterocyte lineage cells in a human intestinal organoid model. We observed similar infection rates of enterocyte-precursors and enterocytes whereas ACE2 expression increases 1000fold upon differentiation at the mRNA level (fig. S2). This suggests that low levels of ACE2 may be sufficient for viral entry.

SARS-CoV-2 is the third highly pathogenic coronavirus (after SARS-CoV and MERS-CoV) to jump to humans within less than 20 years suggesting that novel zoonotic coronavirus spillovers are likely to occur in the future. Despite this, limited information is available on coronavirus pathogenesis and transmission. This is in part due to the lack of in vitro cell models that accurately model host tissues. Very recently, it was shown that human iPS cells differentiated toward a kidney fate support replication of SARS-CoV-2 (13). Our data imply that human organoids represent faithful experimental models to study the biology of coronaviruses.

\section{REFERENCES AND NOTES}

1. C. Drosten, S. Günther, W. Preiser, S. van der Werf, H.-R. Brodt, S. Becker, H. Rabenau, M. Panning, L. Kolesnikova, R. A. M. Fouchier, A. Berger, A.-M. Burguière, J. Cinatl, M. Eickmann, N. Escriou, K. Grywna, S. Kramme, J.-C. Manuguerra, S. Müller, V. Rickerts, M. Stürmer, S. Vieth, H.-D. Klenk, A. D. M. E. Osterhaus, H. Schmitz, H. W. Doerr, Identification of a novel coronavirus in patients with severe acute respiratory syndrome. N. Engl. J. Med. 348, 1967-1976 (2003). doi:10.1056/NEJMoa030747 Medline

2. W. J. Guan, Z. Y. Ni, Y. Hu, W. H. Liang, C. Q. Ou, J. X. He, L. Liu, H. Shan, C. L. Lei, D. S. C. Hui, B. Du, L. J. Li, G. Zeng, K.-Y. Yuen, R. C. Chen, C. L. Tang, T. Wang, P. Y. Chen, J. Xiang, S. Y. Li, J. L. Wang, Z. J. Liang, Y. X. Peng, L. Wei, Y. Liu, Y. H. Hu, P. Peng, J. M. Wang, J. Y. Liu, Z. Chen, G. Li, Z. J. Zheng, S. Q. Qiu, J. Luo, C. J. Ye, S. Y. Zhu, N. S. Zhong; China Medical Treatment Expert Group for Covid-19, Clinical characteristics of coronavirus disease 2019 in China. N. Engl. J. Med. 382, 17081720 (2020). doi:10.1056/NEJMoa2002032 Medline

3. S. Jiang, L. Du, Z. Shi, An emerging coronavirus causing pneumonia outbreak in Wuhan, China: Calling for developing therapeutic and prophylactic strategies. Emerg. Microbes Infect. 9, 275-277 (2020). doi:10.1080/22221751.2020.1723441 Medline

4. N. Zhu, D. Zhang, W. Wang, X. Li, B. Yang, J. Song, X. Zhao, B. Huang, W. Shi, R. Lu, P. Niu, F. Zhan, X. Ma, D. Wang, W. Xu, G. Wu, G. F. Gao, W. Tan; China Novel Coronavirus Investigating and Research Team, A novel coronavirus from patients with pneumonia in China, 2019. N. Engl. J. Med. 382, 727-733 (2020). doi:10.1056/NEJMoa2001017Medline

5. K. G. Andersen, A. Rambaut, W. I. Lipkin, E. C. Holmes, R. F. Garry, The proximal origin of SARS-CoV-2. Nat. Med. 26, 450-452 (2020). doi:10.1038/s41591-0200820-9 Medline

6. R. Lu, X. Zhao, J. Li, P. Niu, B. Yang, H. Wu, W. Wang, H. Song, B. Huang, N. Zhu, Y. Bi, X. Ma, F. Zhan, L. Wang, T. Hu, H. Zhou, Z. Hu, W. Zhou, L. Zhao, J. Chen, Y. Meng, J. Wang, Y. Lin, J. Yuan, Z. Xie, J. Ma, W. J. Liu, D. Wang, W. Xu, E. C. Holmes, G. F. Gao, G. Wu, W. Chen, W. Shi, W. Tan, Genomic characterisation and epidemiology of 2019 novel coronavirus: Implications for virus origins and receptor binding. Lancet 395, 565-574 (2020). doi:10.1016/S01406736(20)30251-8 Medline

7. A. E. Gorbalenya, S. C. Baker, R. S. Baric, R. J. de Groot, C. Drosten, A. A. Gulyaeva, B. L. Haagmans, C. Lauber, A. M. Leontovich, B. W. Neuman, D. Penzar, S. Perlman, L. L. M. Poon, D. V. Samborskiy, I. A. Sidorov, I. Sola, J. Ziebuhr; Coronaviridae Study Group of the International Committee on Taxonomy of Viruses, The species Severe acute respiratory syndrome-related coronavirus: Classifying 2019-nCoV and naming it SARS-CoV-2. Nat. Microbiol. 5, 536-544 (2020). doi:10.1038/s41564-020-0695-z Medline

8. Y. Imai, K. Kuba, S. Rao, Y. Huan, F. Guo, B. Guan, P. Yang, R. Sarao, T. Wada, H. Leong-Poi, M. A. Crackower, A. Fukamizu, C. C. Hui, L. Hein, S. Uhlig, A. S. Slutsky, C. Jiang, J. M. Penninger, Angiotensin-converting enzyme 2 protects from severe acute lung failure. Nature 436, 112-116 (2005). doi:10.1038/nature03712 Medline

9. K. Kuba, Y. Imai, S. Rao, H. Gao, F. Guo, B. Guan, Y. Huan, P. Yang, Y. Zhang, W. Deng, L. Bao, B. Zhang, G. Liu, Z. Wang, M. Chappell, Y. Liu, D. Zheng, A. Leibbrandt, T. Wada, A. S. Slutsky, D. Liu, C. Qin, C. Jiang, J. M. Penninger, A crucial role of angiotensin converting enzyme 2 (ACE2) in SARS coronavirusinduced lung injury. Nat. Med. 11, 875-879 (2005). doi:10.1038/nm1267Medline

10. A. C. Walls, Y. J. Park, M. A. Tortorici, A. Wall, A. T. McGuire, D. Veesler, Structure, function, and antigenicity of the SARS-CoV-2 spike glycoprotein. Cell 181, 281292.e6 (2020). doi:10.1016/i.cell.2020.02.058 Medline

11. Y. Wan, J. Shang, R. Graham, R. S. Baric, F. Li, Receptor recognition by the novel coronavirus from Wuhan: An analysis based on decade-long structural studies of SARS coronavirus. J. Virol. 94, e00127-20 (2020). doi:10.1128/JVI.00127-20 Medline

12. D. Wrapp, N. Wang, K. S. Corbett, J. A. Goldsmith, C. L. Hsieh, O. Abiona, B. S. Graham, J. S. McLellan, Cryo-EM structure of the 2019-nCoV spike in the prefusion conformation. Science 367, 1260-1263 (2020). doi:10.1126/science.abb2507 Medline

13. V. Monteil, H. Kwon, P. Prado, A. Hagelkrüys, R. A. Wimmer, M. Stahl, A. Leopoldi, E. Garreta, C. Hurtado Del Pozo, F. Prosper, J. P. Romero, G. Wirnsberger, H. Zhang, A. S. Slutsky, R. Conder, N. Montserrat, A. Mirazimi, J. M. Penninger, Inhibition of SARS-CoV-2 infections in engineered human tissues using clinicalgrade soluble human ACE2. Cell 10.1016/i.cell.2020.04.004 (2020). Medline

14. F. Qi, S. Qian, S. Zhang, Z. Zhang, Single cell RNA sequencing of 13 human tissues identify cell types and receptors of human coronaviruses. Biochem. Biophys. Res. Commun. 526, 135-140 (2020). doi:10.1016/j,bbrc.2020.03.044 Medline

15. Y. Zhao, Z. Zhao, Y. Wang, Y. Zhou, Y. Ma, W. Zuo, Single-cell RNA expression profiling of ACE2, the receptor of SARS-CoV-2. bioRxiv 2020.01.26.919985 [Preprint]. 9 April 2010. https://doi.org/10.1101/2020.01.26.919985.

16. H. P. Jia, D. C. Look, L. Shi, M. Hickey, L. Pewe, J. Netland, M. Farzan, C. WohlfordLenane, S. Perlman, P. B. McCray Jr., ACE2 receptor expression and severe acute respiratory syndrome coronavirus infection depend on differentiation of human airway epithelia. J. Virol. 79, 14614-14621 (2005). doi:10.1128/JVL.79.23.1461414621.2005 Medline

17. The Human Protein Atlas, ACE2 protein expression summary (2020); 
https://www.proteinatlas.org/ENSG00000130234-ACE2.

18. J. Gu, B. Han, J. Wang, COVID-19: Gastrointestinal manifestations and potential fecal-oral transmission. Gastroenterology 158, 1518-1519 (2020). doi:10.1053/i.gastro.2020.02.054 Medline

19. G. Cholankeril, A. Podboy, V. I. Aivaliotis, B. Tarlow, E. A. Pham, S. Spencer, D. Kim, A. Hsing, A. Ahmed, High prevalence of concurrent gastrointestinal manifestations in patients with SARS-CoV-2: Early experience from California. Gastroenterology 10.1053/igastro.2020.04.008 (2020). Medline

20. W. Wang, Y. Xu, R. Gao, R. Lu, K. Han, G. Wu, W. Tan, Detection of SARS-CoV-2 in different types of clinical specimens. JAMA (2020). 10.1001/jama.2020.3786 Medline

21. M. L. Holshue, C. DeBolt, S. Lindquist, K. H. Lofy, J. Wiesman, H. Bruce, C. Spitters, K. Ericson, S. Wilkerson, A. Tural, G. Diaz, A. Cohn, L. Fox, A. Patel, S. I. Gerber, L. Kim, S. Tong, X. Lu, S. Lindstrom, M. A. Pallansch, W. C. Weldon, H. M. Biggs, T. M. Uyeki, S. K. Pillai; Washington State 2019-nCoV Case Investigation Team, First case of 2019 novel coronavirus in the United States. N. Engl. J. Med. 382, 929936 (2020). doi:10.1056/NEJMoa2001191 Medline

22. F. Xiao, M. Tang, X. Zheng, Y. Liu, X. Li, H. Shan, Evidence for gastrointestinal infection of SARS-CoV-2. Gastroenterology S0016-5085(20)30282-1 (2020). 10.1053/i.gastro.2020.02.055 Medline

23. T. Sato, D. E. Stange, M. Ferrante, R. G. J. Vries, J. H. Van Es, S. Van den Brink, W. J. Van Houdt, A. Pronk, J. Van Gorp, P. D. Siersema, H. Clevers, Long-term expansion of epithelial organoids from human colon, adenoma, adenocarcinoma, and Barrett's epithelium. Gastroenterology 141, 1762-1772 (2011). doi:10.1053/i.gastro.2011.07.050 Medline

24. K. Ettayebi, S. E. Crawford, K. Murakami, J. R. Broughman, U. Karandikar, V. R. Tenge, F. H. Neill, S. E. Blutt, X. L. Zeng, L. Qu, B. Kou, A. R. Opekun, D. Burrin, D. Y. Graham, S. Ramani, R. L. Atmar, M. K. Estes, Replication of human noroviruses in stem cell-derived human enteroids. Science 353, 1387-1393 (2016). doi:10.1126/science. aaf5211 Medline

25. J. Beumer, B. Artegiani, Y. Post, F. Reimann, F. Gribble, T. N. Nguyen, H. Zeng, M. Van den Born, J. H. Van Es, H. Clevers, Enteroendocrine cells switch hormone expression along the crypt-to-villus BMP signalling gradient. Nat. Cell Biol. 20 , 909-916 (2018). doi:10.1038/s41556-018-0143-y Medline

26. W. K. Leung, K. F. To, P. K. S. Chan, H. L. Y. Chan, A. K. L. Wu, N. Lee, K. Y. Yuen, J. J. Y. Sung, Enteric involvement of severe acute respiratory syndrome-associated coronavirus infection. Gastroenterology 125, 1011-1017 (2003). doi:10.1016/i.gastro.2003.08.001 Medline

27. W. S. Chan, C. Wu, S. C. S. Chow, T. Cheung, K. F. To, W. K. Leung, P. K. S. Chan, K. C. Lee, H. K. Ng, D. M. Y. Au, A. W. I. Lo, Coronaviral hypothetical and structural proteins were found in the intestinal surface enterocytes and pneumocytes of severe acute respiratory syndrome (SARS). Mod. Pathol. 18, 1432-1439 (2005). doi:10.1038/modpathol.3800439 Medline

28. F. G. A. Faas, M. C. Avramut, B. M. van den Berg, A. M. Mommaas, A. J. Koster, R. B. G. Ravelli, Virtual nanoscopy: Generation of ultra-large high resolution electron microscopy maps. J. Cell Biol. 198, 457-469 (2012). doi:10.1083/jcb.201201140 Medline

29. K. Knoops, M. Kikkert, S. H. Worm, J. C. Zevenhoven-Dobbe, Y. van der Meer, A. J. Koster, A. M. Mommaas, E. J. Snijder, SARS-coronavirus replication is supported by a reticulovesicular network of modified endoplasmic reticulum. PLOS Biol. 6, e226 (2008). doi:10.1371/journal.pbio.0060226 Medline

30. N. S. McNutt, W. R. Crain, Quantitative electron microscopic comparison of lymphocyte nuclear contours in mycosis fungoides and in benign infiltrates in skin. Cancer 47, 698-709 (1981). doi:10.1002/10970142(19810215)47:4<698:AID-CNCR2820470413>3.0.C0:2-Z Medline

31. M. Hosmillo, Y. Chaudhry, K. Nayak, F. Sorgeloos, B. K. Koo, A. Merenda, R. Lillestol, L. Drumright, M. Zilbauer, I. Goodfellow, Norovirus replication in human intestinal epithelial cells is restricted by the interferon-induced JAK/STAT signaling pathway and RNA polymerase II-mediated transcriptional responses. mBio 11, e00215-20 (2020). doi:10.1128/mBio.00215-20 Medline

32. K. Saxena, L. M. Simon, X. L. Zeng, S. E. Blutt, S. E. Crawford, N. P. Sastri, U. C. Karandikar, N. J. Ajami, N. C. Zachos, O. Kovbasnjuk, M. Donowitz, M. E. Conner, C. A. Shaw, M. K. Estes, A paradox of transcriptional and functional innate interferon responses of human intestinal enteroids to enteric virus infection. Proc. Natl. Acad. Sci. U.S.A. 114, E570-E579 (2017). doi:10.1073/pnas.1615422114
Medline

33. C. G. Drummond, A. M. Bolock, C. Ma, C. J. Luke, M. Good, C. B. Coyne Enteroviruses infect human enteroids and induce antiviral signaling in a cell lineage-specific manner. Proc. Natl. Acad. Sci. U.S.A. 114, 1672-1677 (2017). do::10.1073/pnas.1617363114 Medline

34. C. Good, A. I. Wells, C. B. Coyne, Type III interferon signaling restricts enterovirus 71 infection of goblet cells. Sci. Adv. 5, eaau4255 (2019) doi:10.1126/sciadv.aau4255 Medline

35. D. Blanco-Melo, B. E. Nilsson-Payant, W.-C. Liu, S. Uhl, D. Hoagland, R. Møller, T. X. Jordan, K. Oishi, M. Panis, D. Sachs, T. T. Wang, R. E. Schwartz, J. K. Lim, R. A. Albrecht, B. R. Tenoever, Imbalanced host response to SARS-CoV-2 drives development of COVID-19. Cell 10.1016/i.cell.2020.04.026 (2020).

36. N. Sachs, A. Papaspyropoulos, D. D. Zomer-van Ommen, I. Heo, L. Böttinger, D. Klay, F. Weeber, G. Huelsz-Prince, N. lakobachvili, G. D. Amatngalim, J. de Ligt, A. van Hoeck, N. Proost, M. C. Viveen, A. Lyubimova, L. Teeven, S. Derakhshan, J. Korving, H. Begthel, J. F. Dekkers, K. Kumawat, E. Ramos, M. F. van Oosterhout, G. J. Offerhaus, D. J. Wiener, E. P. Olimpio, K. K. Dijkstra, E. F. Smit, M. van der Linden, S. Jaksani, M. van de Ven, J. Jonkers, A. C. Rios, E. E. Voest, C. H. van Moorsel, C. K. van der Ent, E. Cuppen, A. van Oudenaarden, F. E. Coenjaerts, L. Meyaard, L. J. Bont, P. J. Peters, S. J. Tans, J. S. van Zon, S. F. Boj, R. G. Vries, J. M. Beekman, H. Clevers, Long-term expanding human airway organoids for disease modeling. EMBO J. 38, 100300 (2019). doi:10.15252/embj.2018100300 Medline

37. V. M. Corman, O. Landt, M. Kaiser, R. Molenkamp, A. Meijer, D. K. Chu, T. Bleicker, S. Brünink, J. Schneider, M. L. Schmidt, D. G. Mulders, B. L. Haagmans, B. van der Veer, S. van den Brink, L. Wijsman, G. Goderski, J. L. Romette, J. Ellis, M. Zambon, M. Peiris, H. Goossens, C. Reusken, M. P. Koopmans, C. Drosten, Detection of 2019 novel coronavirus (2019-nCoV) by real-time RT-PCR. Euro Surveill. 10.2807/1560-7917.ES.2020.25.3.2000045 (2020). Medline

38. J. Muñoz, D. E. Stange, A. G. Schepers, M. van de Wetering, B.-K. Koo, S. Itzkovitz, R. Volckmann, K. S. Kung, J. Koster, S. Radulescu, K. Myant, R. Versteeg, O. J. Sansom, J. H. van Es, N. Barker, A. van Oudenaarden, S. Mohammed, A. J. R. Heck, $\mathrm{H}$. Clevers, The Lgr5 intestinal stem cell signature: Robust expression of proposed quiescent ' +4 ' cell markers. EMBO J. 31, 3079-3091 (2012) doi:10.1038/emboi.2012.166 Medline

39. T. Hashimshony, N. Senderovich, G. Avital, A. Klochendler, Y. de Leeuw, L. Anavy, D. Gennert, S. Li, K. J. Livak, O. Rozenblatt-Rosen, Y. Dor, A. Regev, I. Yanai, CELSeq2: Sensitive highly-multiplexed single-cell RNA-Seq. Genome Biol. 17, 77 (2016). doi:10.1186/s13059-016-0938-8 Medline

40. S. Simmini, M. Bialecka, M. Huch, L. Kester, M. van de Wetering, T. Sato, F. Beck, A. van Oudenaarden, H. Clevers, J. Deschamps, Transformation of intestinal stem cells into gastric stem cells on loss of transcription factor $\mathrm{Cdx2}$. Nat. Commun. $\mathbf{5}$, 5728 (2014). doi:10.1038/ncomms6728 Medline

41. H. Li, R. Durbin, Fast and accurate long-read alignment with Burrows-Wheeler transform. Bioinformatics 26, 589-595 (2010). doi:10.1093/bioinformatics/btp698 Medline

42. M. I. Love, W. Huber, S. Anders, Moderated estimation of fold change and dispersion for RNA-seq data with DESeq2. Genome Biol. 15, 550 (2014). doi:10.1186/s13059-014-0550-8 Medline

43. V. Kaimal, E. E. Bardes, S. C. Tabar, A. G. Jegga, B. J. Aronow, ToppCluster: A multiple gene list feature analyzer for comparative enrichment clustering and network-based dissection of biological systems. Nucleic Acids Res. 38, W96W102 (2010). doi:10.1093/nar/gkq418 Medline

44. J.-M. Burel, S. Besson, C. Blackburn, M. Carroll, R. K. Ferguson, H. Flynn, K. Gillen, R. Leigh, S. Li, D. Lindner, M. Linkert, W. J. Moore, B. Ramalingam, E. Rozbicki, A. Tarkowska, P. Walczysko, C. Allan, J. Moore, J. R. Swedlow, Publishing and sharing multi-dimensional image data with OMERO. Mamm. Genome 26, 441-447 (2015). doi:10.1007/s00335-015-9587-6 Medline

\section{ACKNOWLEDGMENTS}

We thank E. Eenjes and R. Rottier for providing human lung material, A. de Graaff and Hubrecht Imaging Centre (HIC) for microscopy assistance and Single Cell Discoveries for RNA library preparation, and the Utrecht Sequencing Facility (subsidized by the University Medical Center Utrecht, Hubrecht Institute, Utrecht University and NWO project 184.034.019). Funding: This work was 
supported by ERC Advanced Grant 67013 and by Lung Foundation Netherlands to HC, and by NWO Grant 022.005.032. K.K., J.Q.D., P.J.P., and R.B.G.R. received funding from the Dutch Technology Foundation STW (UPON 14207) and from European Union's Horizon 2020 Programme, Grant Agreement No 766970 Q-SORT. Author contributions: M.L., J.B., and J.V. performed experiments and designed the study. K.K. and J.Q.D. prepared samples. K.K. and R.B.G.R. performed imaging. K.K., J.P.v.S., P.J.P., and R.G.B.R. interpreted results. T.B., A.M., S.R., D.S., and M.G. measured virus titers. J.P. analyzed RNAseq data. E.C. performed sequencing. M.K., B.H., and H.C. supervised. Competing interests: H.C. is inventor on patents held by the Royal Netherlands Academy of Arts and Sciences that cover organoid technology.:

PCT/NL2008/050543, W02009/022907; PCT/NL2010/000017. W02010/090513; PCT/IB2011/002167, W02012/014076;

PCT/IB2012/052950, W02012/168930;PCT/EP2015/060815,

W02015/173425; PCT/EP2015/077990, WO2016/083613;

PCT/EP2015/077988, W02016/083612;

PCT/EP2017/054797,W02017/149025; PCT/EP2017/065101, W02017/220586; PCT/EP2018/086716, and GB1819224.5. H.C.'s full

disclosure is given athttps://www.uu.n//staff/JCClevers/. Data and materials availability: Organoid lines may be requested directly from the non-profit HUB (https://huborganoids. nl/), which does not directly benefit from this research. RNA sequence data can be accessed through GEO GSE149312. This work is licensed under a Creative Commons Attribution 4.0 International (CC BY 4.0) license, which permits unrestricted use, distribution, and reproduction in any medium, provided the original work is properly cited. To view a copy of this license, visit https://creativecommons.org/licenses/by/4.0/. This license does not apply to figures/photos/artwork or other content included in the article that is credited to a third party; obtain authorization from the rights holder before using such material.

\section{SUPPLEMENTARY MATERIALS}

science.sciencemag.org/cgi/content/full/science.abc1669/DC1

Materials and Methods

Figs. S1 to S14

Tables S1 to S4

References (36-44)

MDAR Reproducibility Checklist

9 April 2020; accepted 29 April 2020

Published online 1 May 2020

10.1126/science.abc1669 

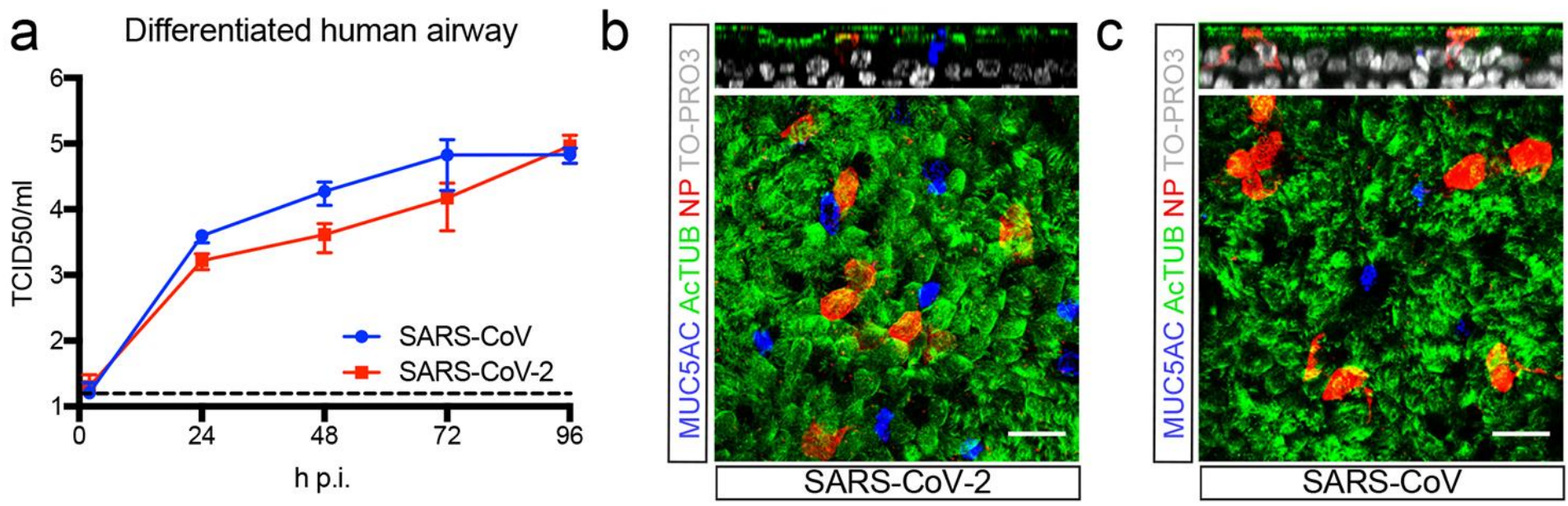

Fig. 1. SARS-CoV and SARS-CoV-2 infect 2D human airway cultures. (a) Live virus titers can be observed by virus titrations on VeroE6 cells of apical washes at 2, 24, 48, 72 and $96 \mathrm{~h}$ after infection with SARS-CoV (blue) and SARS-CoV2 (red). The dotted line indicates the lower limit of detection. Error bars represent SEM. $N=4 .{ }^{*} \mathrm{P}<0.05,{ }^{*} \mathrm{P}<0.01$, ${ }^{* * *} \mathrm{P}<0.001$. (b and c) Immunofluorescent staining of SARS-CoV-2 (b) and SARS-CoV (c) infected differentiated airway cultures. Nucleoprotein (NP) stains viral nucleocapsid (red), which colocalized with the ciliated cell marker AcTUB (green). Goblet cells are identified by MUC5AC (blue). Nuclei are stained with TO-PRO3 (white). Scale bars indicate $20 \mu \mathrm{M}$. Top panels are side-view while bottom panels are top-view. 
a

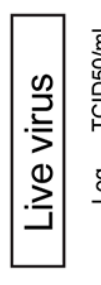

e

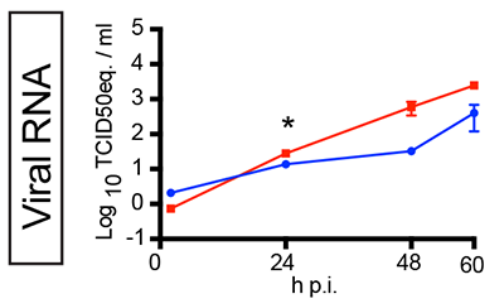

b

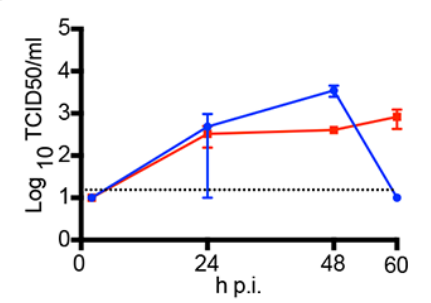

f

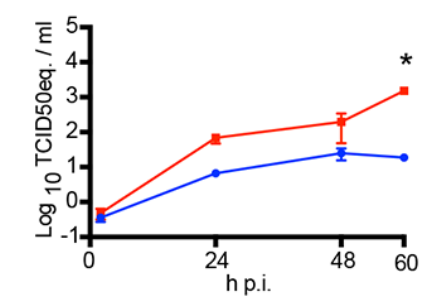

C

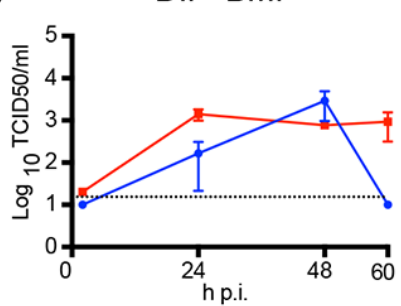

g

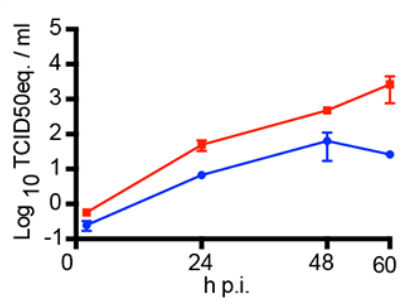

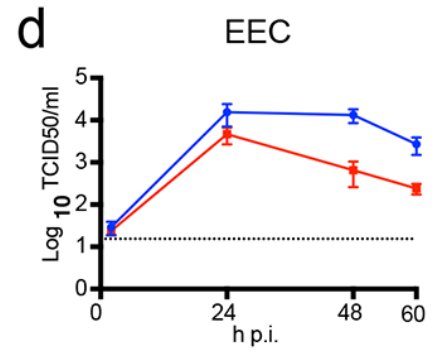

$\mathrm{h}$

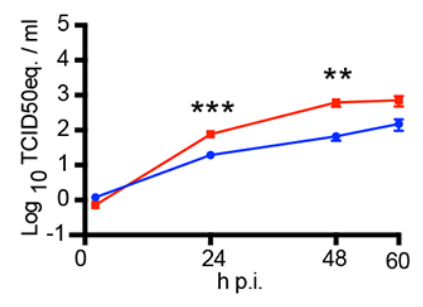

Fig. 2. SARS-CoV and SARS-CoV-2 replicate in hSIOs. (a to d) Live virus titers can be observed by virus titrations on VeroE6 cells of lysed organoids at 2, 24, 48 and 60h after infection with SARS-CoV (blue) and SARS-CoV-2 (red). Different medium compositions show similar results. (e to $h$ ) qPCR analysis targeting the E gene of similar timepoints and medium compositions as (a) to (d). The dotted line indicates the lower limit of detection. Error bars represent SEM. $N=3$. ${ }^{*} \mathrm{P}<0.05$, ${ }^{*} \mathrm{P}<0.01$, ${ }^{* * *} \mathrm{P}<0.001$. 
a
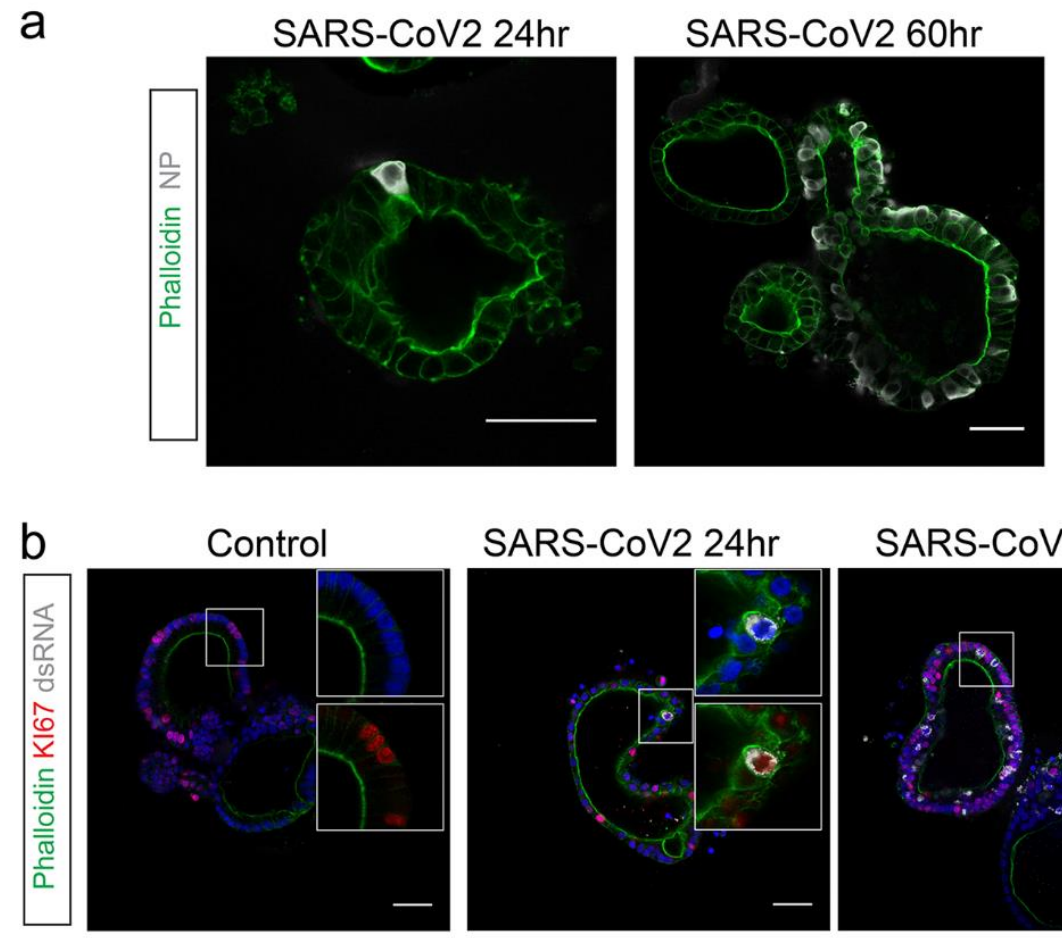

SARS-CoV2 60hr
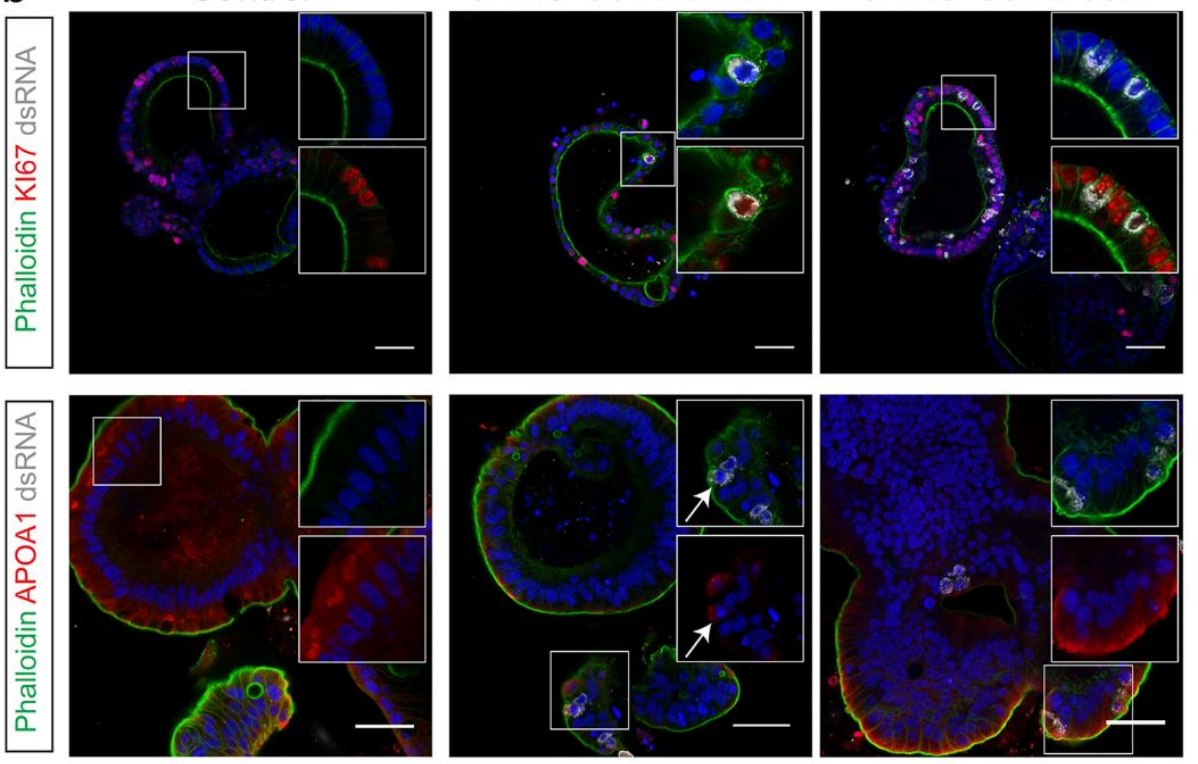

C

EXP
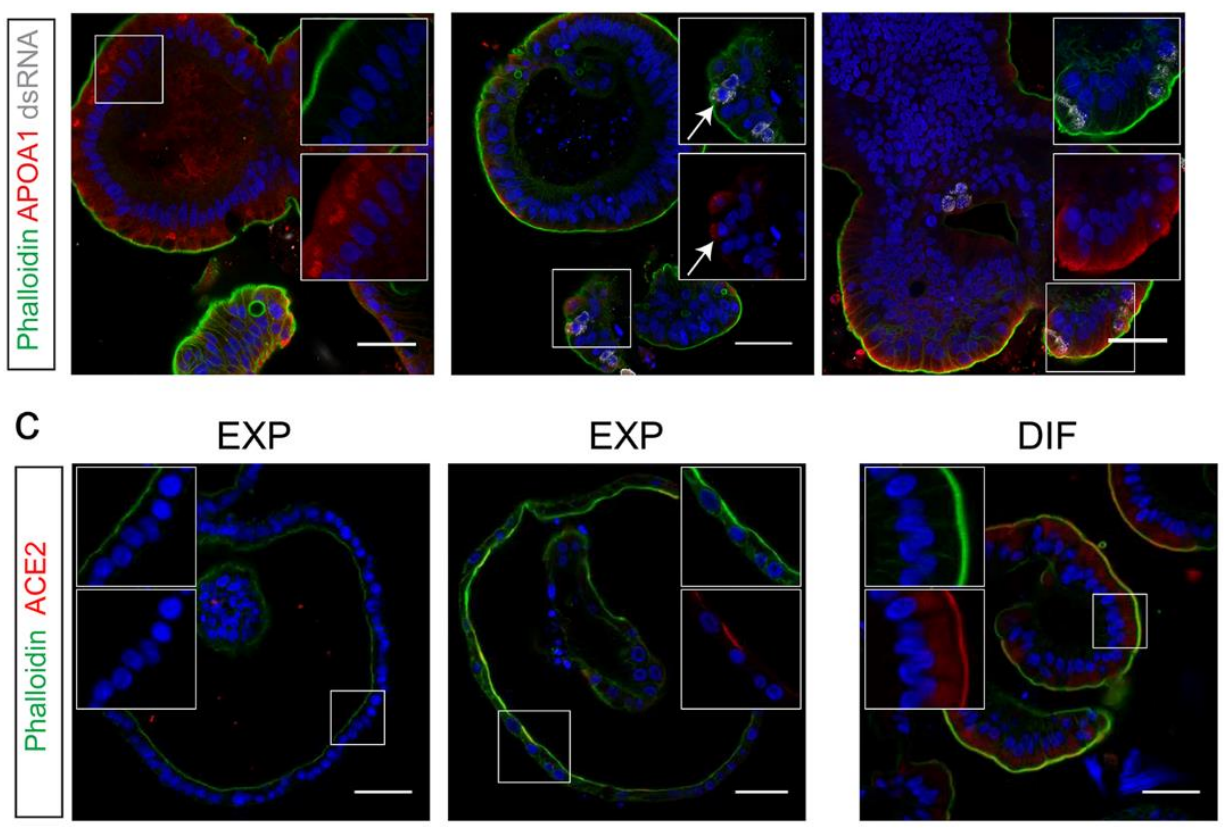

Fig. 3. SARS-CoV-2 infects proliferating cells and enterocytes. (a) Immunofluorescent staining of SARSCoV-2-infected intestinal organoids. Nucleoprotein (NP) stains viral capsid. After 24 hours, single virusinfected cells are generally observed in organoids. These small infection clusters spread through the whole organoid after 60 hours. (b) SARS-CoV-2 infects both post-mitotic enterocytes identified by Apolipoprotein Al (APOA1) and dividing cells that are K167-positive. Infected cells are visualized by dsRNA staining. Enterocytes are shown in differentiated organoids, and proliferating cells in expanding organoids. Arrows point to APOA1-positive cells. (c) Immunofluorescent staining of ACE2 in intestinal organoids in expansion and differentiation condition. All scale bars are $50 \mu \mathrm{m}$. 

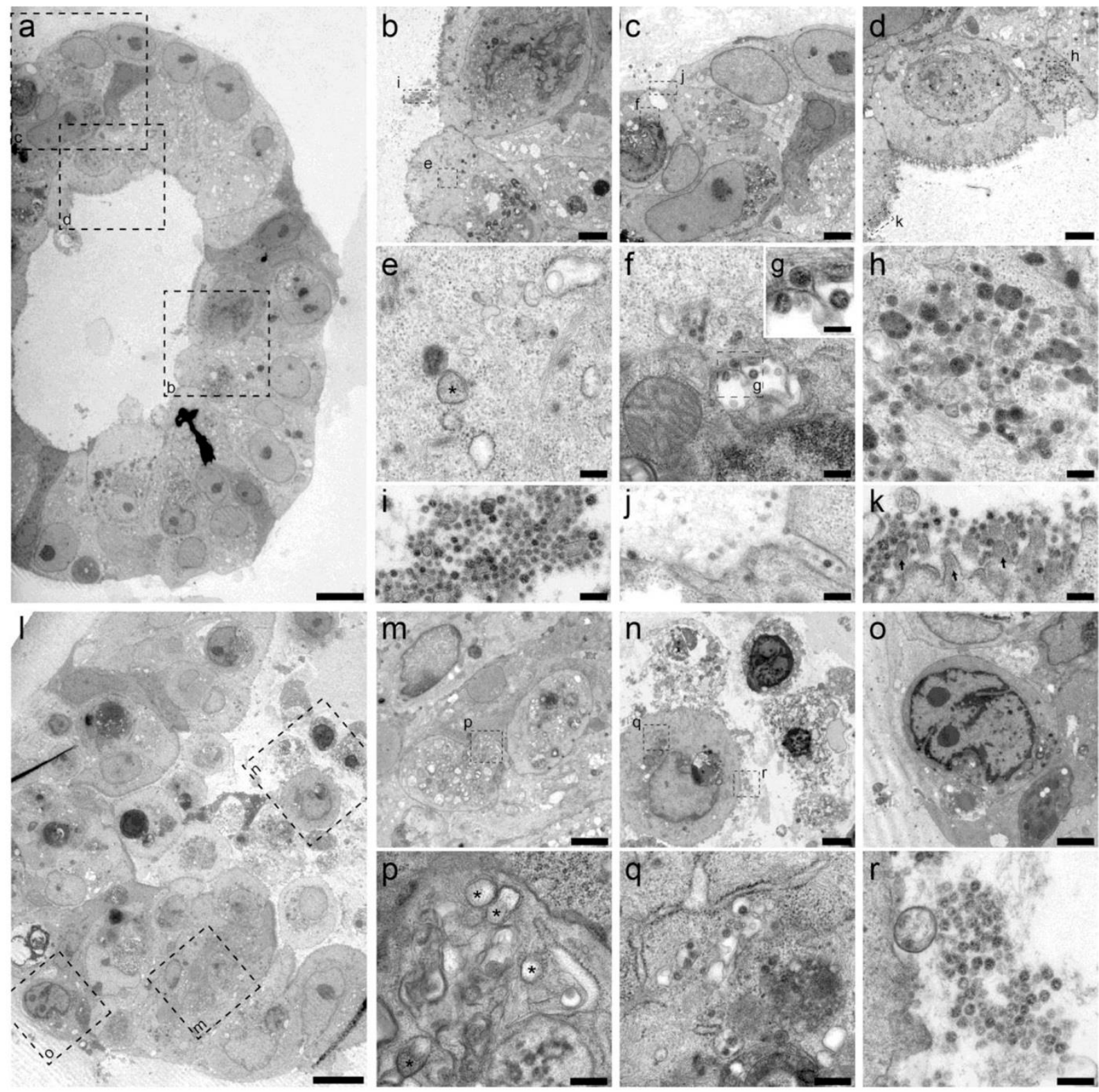

Fig. 4. Transmission electron microscopy analysis of SARS-CoV-2 infected intestinal organoids. ( $a$ to $h$ ) Overview of an intact organoid (a) showing the onset of virus infection (b to d) at different stages of the viral lifecycle, i.e., early double membrane vesicles (DMVs) [(e), asterisk], initial viral production in the Golgi apparatus [(f) and (g)] and complete occupation of virus particles inside the endomembrane system (h). (i to k) Extracellular viruses are observed in the lumen of the organoid (i), and are found at the basal (j) and apical side (k) alongside the microvilli (arrows). Scale bars represent $10 \mu \mathrm{m}(\mathrm{a}), 2.5 \mu \mathrm{m}$ [(b) to (d)], $250 \mathrm{~nm}[(\mathrm{e})$, (f), and (h) to (k)] and $100 \mathrm{~nm}$ (g). (I to q) Overview of an organoid (I) showing severely infected cells $[(\mathrm{m})$ and $(0)]$, disintegrated cells $(0)$ and stressed cells as evident from the atypical nucleoli $(p)$. Intact cells reveal DMV areas of viral replication [(p), asterisks] and infected Golgi apparatus (q). ( $r$ ) Extracellular clusters of viruses. Scale bars represent $10 \mu \mathrm{m}(\mathrm{I}), 2.5 \mu \mathrm{m}[(\mathrm{m})$ to $(\mathrm{p})]$ and $250 \mathrm{~nm}[(\mathrm{p})$ to $(r)]$. Data was deposited to the Image Data Resource (https://idr.openmicroscopy.org) under accession number idr0083. 

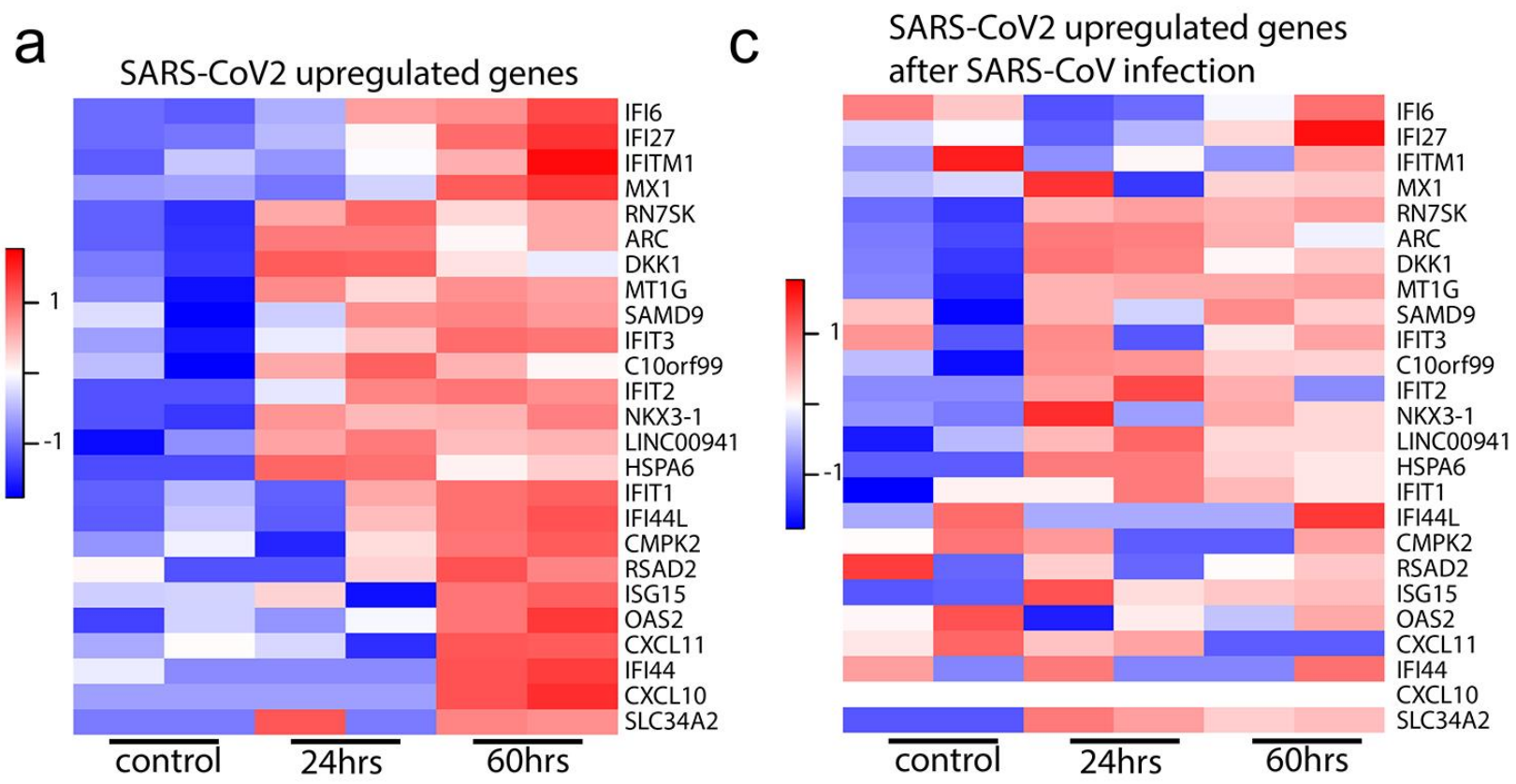

b

\begin{tabular}{l|l|l|l} 
& ID & Name & pValue \\
\hline 1 & GO:0051607 & defense response to virus & $3.568 E-24$ \\
\hline 2 & GO:0009615 & response to virus & $2.325 E-23$ \\
\hline 3 & GO:0071357 & cellular response to type I interferon & $2.687 \mathrm{E}-18$ \\
\hline 4 & GO:0060337 & type I interferon signaling pathway & $2.687 \mathrm{E}-18$ \\
\hline 5 & GO:0034340 & response to type I interferon & $4.515 \mathrm{E}-18$
\end{tabular}

Fig. 5. Transcriptomic analysis of SARS-CoV-2 infected intestinal organoids. (a) Heatmaps depicting the 25 most significantly enriched genes upon SARS-CoV-2 infection in expanding intestinal organoids. (b) Colored bar represents Z-score of log2 transformed values. GO term enrichment analysis for biological processes of the 50 most significantly up-regulated genes upon SARS-CoV-2 infected in intestinal organoids. (c) Heatmaps depicting the genes from (a) in SARS-CoV infected expanding organoids. Colored bar represents Z-score of log2 transformed values. 